\title{
ANALISIS RISIKO PAPARAN ISOPROPANOL PADA PEKERJA OFFSET PRINTING
}

\author{
Nunik Ekawandani \\ Dosen Teknik Kimia Politeknik TEDC Bandung \\ Jl. Pasantren Km. 2, Cibabat Cimahi \\ Email : nunik.ekawandani@gmail.com
}

\begin{abstract}
Abstrak
Pelarut di industri percetakan merupakan bahan kimia yang paling sering digunakan baik sebagai bahan pencampur maupun pencuci. Jenis pelarut yang digunakan di industri percetakan tersebut salah satunya adalah isopropanol. Isopropanol adalah cairan yang mudah menguap, dengan kelarutan yang tinggi dalam air dan pelarut organik. Hal ini mengakibatkan jalur paparan isopropanol yang paling utama adalah melalui rute inhalasi. Efek yang ditimbulkan dari isopropanol dapat menyebabkan efek neurologis dan toksisitas ginjal kronis. Studi ini membahas mengenai analisis risiko pengaruh paparan isopropanol melalui inhalasi terhadap pekerja percetakan di kawasan percetakan Pagarsih, Kota Bandung. Penelitian ini bertujuan untuk mengidentifikasi paparan isopropanol dan mengevaluasi faktor-faktor yang mempengaruhi paparan isopropanol pada pekerja percetakan offset. Penelitian ini merupakan penelitian epidemiologi cross sectional. Responden yang dilibatkan dalam penelitian ini sebanyak 30 responden terpapar dan 10 responden kontrol. Penelitian ini dilakukan dengan mengambil sampling konsentrasi isopropanol di udara, dengan metode $\mathrm{NIOSH} 1400$ issue 2. Pengambilan sampel di udara dilakukan dengan personal sampler pump dengan absorber berupa karbon aktif (coconut shell charcoa). Hasil sampling kemudian dianalisa dengan menggunakan Gas Chromatography, Flame Ionization Detector (GC-FID). Hasil pengukuran konsentrasi rata-rata isopropanol di udara adalah $237,5317 \mathrm{ppm}$. Biomarker paparan isopropanol dilakukan melalui pengukuran kristal oksalat dalam urin. Hasil analisis kristal oksalat pada urin menunjukan persentase sebesar 23,33\% pada rentang kuantitas kristal oksalat 1-5 LPK; 43,33\% pada rentang hasil 5-10 LPK; $26,67 \%$ pada rentang hasil 10-30 LPK, dan 6,67\% pada rentang hasil >30 LPK. Dari hasil uji statistik menggunakan regresi logistik multinomial, faktor-faktor yang mempengaruhi jumlah kristal oksalat dalam urin adalah konsentrasi isopropanol di udara, penggunaan alat pelindung diri (masker) dan faktor usia pekerja.
\end{abstract}

Kata kunci: isopropanol, percetakan offset, pekerja percetakan, kristal oksalat

\begin{abstract}
Solvents in printing industries has become the most common materials used both as addictive ingredients and dishwashers. The type of solvent used in the printing industry is isopropanol. Isopropanol is a volatile liquid that is soluble in water and organic solvents, the exposure pathways isopropanol most is through inhalation. The effects of isopropanol can cause neurological effects and chronic renal toxicity. This study will be discussed on a risk analysis of the effect of isopropanol through inhalation exposure of workers Pagarsih printing in the printing area, Bandung. This study aims also to identify exposure to isopropanol, evaluating affecting worker exposure to isopropanol in offset printing. This study is a cross sectional epidemiology. This research involved 30 respondents who were considered exposed to isopropanol and 10 respondents as a control. This research was conducted by taking air sampling to measure the concentration of isopropanol, with the issue 2 of NIOSH method 1400. Sampling was carried out with a personal air sampler pump with material absorbents of activated carbon (coconut shell charcoal), then the sample were analyzed by using Gas Chromatography, Flame Ionization Detector (FID). The result of the analysis measurement of the concentration of isopropanol in average air is $237,5317 \mathrm{ppm}$. The effects of exposure used biomarkers by analyzing the oxalate crystals in the urine of workers. Results of oxalate crystals in the urine analysis showed the percentage of $23.33 \%$ on the result $1-5 \mathrm{HP}, 43.33 \%$ on the results of $5-10 \mathrm{HPF}, 26.67 \%$ in the $10-30 \mathrm{HPF}$ and $6.67 \%$ on the results $>30$ HPF. Statistical results using multinomial logistic regression showed that effects of the amount of oxalate crystals in the urine were the concentration of isopropanol in the air, the use of PPE (masks), and due to age workers.
\end{abstract}

Keywords: isopropanol , printing offset, printing workers, oxalate crystals 


\section{PENDAHULUAN}

Percetakan di Indonesia merupakan industri yang sangat jarang diperhatikan oleh petugas kesehatan maupun oleh pemerintah, terutama mengenai kesehatan dan keselamatan pekerjanya (Ashari dkk, 2013). Percetakan merupakan suatu industri produktif yang terus berkembang dan memperbaharui teknologinya. Risiko dalam industri percetakan dapat berupa risiko gangguan kesehatan pada pekerjanya, maupun risiko dari bahan kimia yang dapat menyebabkan kebakaran. Bahan kimia yang banyak digunakan di dalam industri percetakan adalah pelarut. Penggunaan pelarut organik di industri percetakan telah dikaitkan dengan keracunan akut dan penurunan kinerja karyawan (Svendsen, 2000). Penggunaan pelarut organik merupakan bahaya potensial bagi kesehatan, produktivitas, dan efisiensi kerja di banyak lingkungan kerja dan industri (Soemirat, 2000). Jutaan pekerja telah terpapar pelarut organik dalam pekerjaannya, namun hanya sedikit yang mengetahui tentang efek kesehatan yang dapat ditimbulkan dari paparan pelarut organik tersebut (Tak-Sun Yu, 2005).

Isopropanol merupakan salah satu pelarut yang banyak digunakan di industri dan rumah tangga (Brugnone, 1983). Isopropanol dikategorikan sebagai Volatile Organic Compounds (VOC) yang dapat merusak lapisan atmosfir. Secara spesifik isopropanol digunakan untuk pembersih tinta dan mempercepat pengering minyak dan tinta tanpa meninggalkan residu pada rol mesin cetak offset (Deshpande, 2011).

Studi farmakokinetik terhadap pria yang dalam pekerjaannya terpapar isopropanol menunjukan serapan yang paling mudah terjadi adalah melalui rute inhalasi (Brugnone et al., 1983).

Isopropanol juga bersifat toksik pada ginjal dan dapat menyebabkan efek gagal ginjal kronis pada tikus dengan perlakuan melalui rute inhalasi pada dosis 5000 ppm (Burleigh-Flayer et al.,1997). Studi paparan isopropanol pada tikus menunjukkan adanya efek pada perkembangan dan reproduksi (Bevan et al.,1995; Tyl et al., 2004).

Isopropanol dengan cepat diserap dari saluran pencernaan, dengan persentase sebesar lebih dari $80 \%$ dalam waktu 30 menit dan penyerapan sebesar $100 \%$ hanya dalam waktu 3 jam. Sebaliknya, kemampuan penyerapan/paparan isopropanol melalui kulit dapat dikategorikan cukup rendah (Martinez et al, 1986; McGrath \& Einterz, 1989). Di dalam tubuh, Isopropanol dimetabolisme menjadi aseton. Utamanya aseton akan tereliminasi melalui paruparu, meskipun akan dikeluarkan juga melalui urin. Konsentrasi aseton pada urin akan lebih tinggi keesokan harinya (pada pagi hari) dibandingkan setelah selesai bekerja. Stadium terakhir keracunan didominasi oleh gagal ginjal dengan oliguria, proteinuria dan sejumlah besar kristal oksalat dalam sedimen kemih.(WHO, 1986).

Analisis risiko merupakan metode yang akan digunakan dalam penelitian ini untuk menilai dan melakukan prediksi efek yang akan terjadi akibat pajanan isopropanol terhadap pekerja percetakan di Pagarsih Bandung. Metode ini digunakan untuk menilai faktor bahaya isopropanol sehingga dapat dilakukan tindakan pencegahan terhadap menurunnya tingkat kesehatan pekerja percetakan akibat paparan isopropanol terinhalasi. Untuk mencapai maksud tersebut, maka penelitian ini akan memenuhi tujuan-tujuan sebagai berikut:

- Identifikasi paparan isopropanol di lingkungan kerja pada percetakan offset printing

- Evaluasi paparan isopropanol pada pekerja di percetakan offset printing.

- Evaluasi efek paparan isopropanol pada pekerja di percetakan offset printing, melalui pengecekan kristal oksalat dalam urin.

\section{METODE PENELITIAN}

Penelitian ini merupakan penelitian epidemiologi cross sectional. Penelitian diawali dengan survey lapangan berupa pendataan dan pengisian kuesioner. Responden dipilih dari 11 percetakan yang berada di sentra percetakan Pagarsih, Kota Bandung. Pengambilan sampel dilakukan pada 30 orang pekerja percetakan mesin offset tipe speedmaster merk Haidelberg dan 10 orang yang bekerja pada bagian CTP (Computer to Plat) sebagai kontrol.

Pengukuran parameter fisik dilakukan bersamaan dengan pengambilan sampel udara terinhalasi. Parameter fisik yang diukur meliputi temperatur udara, kelembaban udara, kecepatan angin, dan tekanan udara. Alat yang digunakan untuk mengukur kecepatan angin adalah anemometer, sedangkan untuk mengukur temperatur basah, temperatur kering dan kelembaban udara menggunakan Wet Bulb Globe Temperature (WBGT). Titik pengambilan sampel dilakukan di lokasi dimana pekerja melakukan aktivitas pekerjaannya.

Mesin cetak offset 4 warna yang mengunakan isopropanol sebagai larutan untuk mencuci plat secara otomatis. Pencucian secara otomatis ini mempunyai dampak paparan yang cukup tinggi terhadap kesehatan para operator/pekerja.

Penelitian dilakukan dengan mengukur paparan isopropanol yang terinhalasi oleh pekerja percetakan dengan mengukur udara ambien di sekitar breathing zone pekerja. Alat yang 
digunakan adalah Personal Sample Pumps SKC dengan media Coconut Charcoal 50/100 mg dengan laju alir 0,01 - 0,2 l/menit (NIOSH 1400 issue 2).

Evaluasi efek paparan isopropanol dilakukan dengan mengukur kristal oksalat dalam urin. Pengambilan sampel urin ini dilakukan pada pagi hari. Pengukuran kadar sedimentasi kristal oksalat dalam urin adalah hal penting untuk mendapatkan bukti efek paparan dari isopropanol. Metode yang digunakan untuk mengetahui kristal oksalat dalam urin adalah dengan metode mikroskopis.

Pengukuran zat toksik yang terihalasi selama masa tertentu dapat menentukan efek dari suatu paparan yaitu Chronic Daily Intake (CDI). Perhitungan Chronic Daily Intake (CDI) menurut US EPA EPA's (1986a) Guidelines for Carcinogen Risk Assessment, persamaannya adalah sebagai berikut :

Keterangan :

$$
\mathrm{CDI}=\frac{\mathrm{C} \times \mathrm{IR} \times \mathrm{ET} \times \mathrm{EF} \times \mathrm{ED}}{\mathrm{BW} \times \text { lifetime } \times \mathrm{AT}}
$$

$$
\begin{array}{ll}
\mathrm{CDI} & =\text { Chronic Daily Intake }(\mathrm{mg} / \mathrm{kg}- \\
\text { hari })^{-1} & =\text { Concentration, konsentrasi }
\end{array}
$$$$
\text { paparan rata-rata }\left(\mathrm{mg} / \mathrm{m}^{3}\right)
$$$$
\text { IR } \quad=\text { Inhalation rate }\left(\mathrm{m}^{3} / \mathrm{jam}\right)
$$$$
\text { ET } \quad=\text { Exposure Time (jam/hari) }
$$$$
\mathrm{EF} \quad=\text { Exposure Frequency }
$$

(hari/tahun)

$$
\begin{array}{ll}
\text { ED } & =\text { Exposure Duration (tahun) } \\
\text { BW } & =\text { Body Weight }(\mathrm{kg}) \\
\text { AT } & =\text { Averaging Time (hari) } \\
\text { Lifetime } & =70 \text { tahun }
\end{array}
$$

Analisis statistik yang digunakan dalam penelitian ini adalah uji kesetaraan, uji korelasi dan uji regresi logistik. Model regresi logistik sederhana, dapat menghasilkan log OR (odd ratio) yang stabil, sehingga dapat menentukan seberapa besar pengaruh berbagai faktor determinan terhadap suatu dampak/penyakit (Soemirat, 2013).

\section{HASIL DAN PEMBAHASAN}

Hasil observasi terhadap penggunakan cairan pelarut untuk membersihkan plat cetak pada mesin cetak offset terdiri dari campuran isopropanol $98 \%$, fountain (komposisi : propylene glycol, 2 butoxyethanol dan acetic acid), dan air dengan perbandingan $5: 3: 60$.

\section{Karakteristik Responden}

Hasil analisis statistik menggunakan Mann-Whitney terhadap usia responden terpapar dan kontrol, diketahui nilai p-value 0,302 $(p>0,05)$. Hal ini berarti nilai rerata pada responden terpapar dan kontrol tidak berbeda secara nyata. Pada Gambar 1. digambarkan persentase distribusi usia pada responden terpapar dan kontrol.

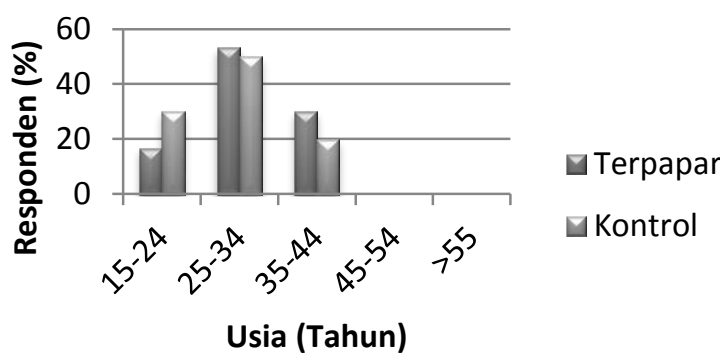

Gambar 1. Distribusi usia responden terpapar dan control

Persentase distribusi masa kerja responden seperti terlihat pada Gambar 2. Hasil statistik menggunakan uji Mann-Whitney, diperoleh angka signifikasi 0,875 ( $p>0,05)$. Hal ini berarti nilai rerata masa kerja responden pada kelompok pekerja terpapar dan kontrol tidak berbeda secara nyata (setara).

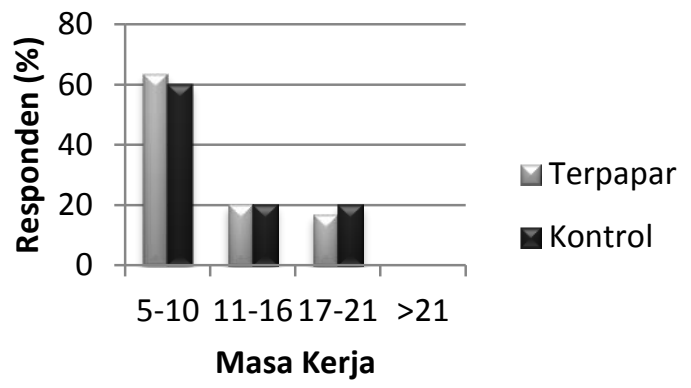

Gambar 2. Distribusi masa kerja responden terpapar dan control

Hasil statistik menggunakan uji MannWhitney, terhadap penggunaan masker diketahui bahwa $\mathrm{p}$ value pada responden terpapar dan kontrol adalah 0,260 ( $p>0,05)$. Hal ini berarti antara penggunaan masker responden pada kelompok pekerja terpapar dan kontrol tidak berbeda secara nyata (setara). Persentase distribusi responden yang menggunakan masker terlihat pada Gambar 3.

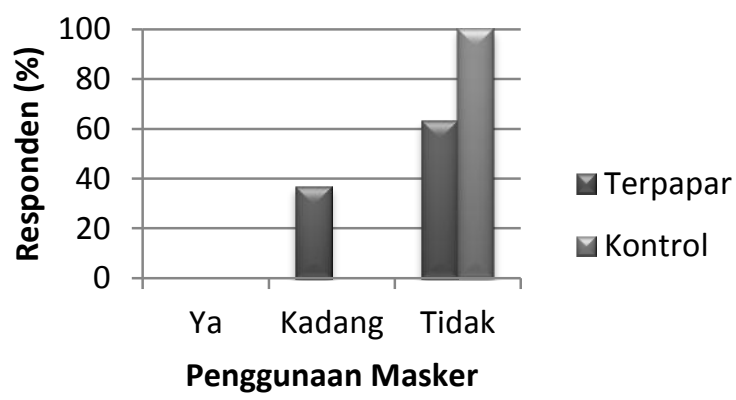

Gambar 3. Distribusi penggunaan masker responden terpapar dan kontrol 


\section{Pengukuran Iklim Lingkungan Kerja}

Nilai distribusi nilai temperatur setelah dihitung dengan menggunakan Uji Mann Whitney adalah sebesar 0,158 ( $p>0,05)$. Dari hasil uji tersebut, maka hasil analisa statistik terhadap responden terpapar dan kontrol tidak berbeda secara nyata. Hasil analisa kelembaban dengan Uji Mann Whitney adalah sebesar 0,06 ( $p>0,05)$ maka- dapat disimpulkan adanya tidak perbedaan secara nyata antara responden terpapar dan kontrol. Dalam penelitian ini hasil pengukuran kecepatan angin tidak terukur sama sekali, dikarenakan lingkungan kerja terletak indoor.

Tabel 1. Parameter Fisika Lingkungan Kerja

\begin{tabular}{|l|c|c|c|}
\hline \multirow{2}{*}{ Parameter } & \multicolumn{2}{|c|}{ Lokasi } & \multirow{2}{*}{ NAB* } \\
\cline { 2 - 3 } & Terpapar & Kontrol & \\
\hline Temperatur & 25,81 & 25,38 & $18-30$ \\
$\left(^{\circ} \mathrm{C}\right)$ & 43,47 & 39,67 & $65-95$ \\
Kelembaban & - & - & $0,15-$ \\
RH (\%) & & & 0,25 \\
Kecepatan & & & \\
Angin (m/s) & & & \\
\hline
\end{tabular}

*NAB berdasarkan Kepmenkes

No. 1405/Menkes/SK/XI/2002

\section{Evaluasi Pengukuran Isopropanol}

Hasil dari pengukuran isopropanol di daerah breathing zone responden terpapar ratarata sebesar 237,53 ppm dengan rentang paparan sebesar 164,52-382,51 ppm. Sedangkan rata-rata paparan pada responden kontrol sebesar 1,52 ppm dengan rentang 1,51-1,58 ppm. Hasil pengukuran isopropanol pada breathing zone ini masih berada di bawah NAB yang ditetapkan oleh NIOSH dan dalam Permennaker sebesar 400 ppm. Besarnya paparan uap isopropanol di udara tergantung kondisi lingkungan kerja dan kondisi fisik di lingkungan kerja. Hasil penghitungan statistik dengan uji Mann Whitney menunjukan hasil signifikasi sebesar $0,00(p<0,05)$, artinya adanya perbedaan bermakna dari hasil pengukuran udara antara responden terpapar dan kontrol. Untuk nilai TWA

\section{Evaluasi Kristal Oksalat pada Urin}

Hasil analisis sedimentasi kristal oksalat pada urine pekerja percetakan pada responden terpapar memperlihatkan persentase sebesar 23,33\% pada hasil 1-5 LPK; 43,33\% pada hasil 5-10 LPK; 26,67\% pada hasil 10-30 LPK dan $6,67 \%$ pada hasil >30 LPK. Sedangkan pada responden kontrol teranalisis hanya pada hasil 0-1 LPK sebesar $100 \%$.

Hasil perhitungan statistik menggunakan uji Mann Whitney antara responden terpapar dan responden kontrol nilai signikasinya adalah 0,000 $(\mathrm{p}<0,05)$ artinya adalah terdapat perbedaan secara nyata antara responden terpapar dan kontrol.
Kristal oksalat yang ditemukan pada urin dapat dilihat seperti pada Gambar 4. Kristal oksalat yang tertangkap mikroskop berbentuk amplop atau helter.

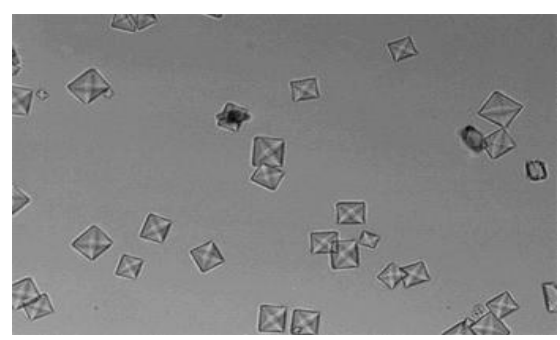

Gambar 4. Kristal oksalat dalam urin dibawah mikroskop (satuan LPK)

Hubungan Kristal Oksalat dengan Faktor Individu Korelasi dengan uji Spearman antara paparan isopropanol dengan kristal oksalat pada urin mempunyai nilai signifikan $0,00(<0,05)$ dan nilai koefisien korelasi 0,566. Artinya terdapat korelasi yang signifikan antara paparan isopropanol dan kristal oksalat pada urin, sedangkan nilai koefisien korelasinya menunjukan korelasi sedang.

Korelasi dengan menggunakan uji Spearman antara indeks masa tubuh (IMT) dengan sedimentasi kristal oksalat di urin menunjukan nilai signifikasi $0,719(>0,05)$ dan koefisien korelasinya adalah 0,566, artinya tidak terdapat korelasi yang signifikan antara indeks masa tubuh (IMT) dengan kristal oksalat pada urin dimana nilai koefiensi korelasinya sedang.

Korelasi dengan uji Spearman antara penggunaan APD (masker) dengan kristal oksalat dalam urin mempunyai nilai signifikan 0,002 $(<0,05)$ dan koefisien korelasinya adalah $-0,473$ artinya mempunyai korelasi yang signifikan dengan nilai koefisien korelasi yang berlawanan arah antara penggunaan APD (masker) dengan kristal oksalat dalam urin. Artinya semakin tidak menggunakan masker semakin tinggi kandungan kristal oksalat pada urin.

Korelasi dengan uji Spearman antara masa kerja dengan kristal oksalat pada urin mempunyai adalah nilai signifikan 0,240 $(>0,05)$ dan nilai koefisien korelasinya 0,190, artinya tidak terdapat korelasi yang signifikan antara masa kerja dan kristal oksalat pada urin, nilai koefisien korelasinya hampir tidak ada korelasi.

\section{Chronic Daily Intake (CDI)}

Nilai CDI seperti pada Gambar 5, responden terpapar dan responden kontrol bervariasi. Variasi tersebut dipengaruhi beberapa faktor seperti konsentrasi isopropanol di udara, usia serta penggunaan masker selama responden bekerja, dan juga dipengaruhi pola hidup para responden tersebut. Pada responden terpapar rentang nilai CDI berkisar 0,0006-0,0018 
$\mathrm{mg} / \mathrm{kg}$.hari dengan rata-rata sebesar $0,0012 \pm 0,0004$. Sedangkan pada responden kontrol rentang nilai CDI 0,0075-0,0288 $\mathrm{mg} / \mathrm{kg}$.hari dengan rata-rata 0,0000008 $\pm 0,0000005$ (Gambar 6 dan Gambar 7). Hasil uji Kolmogorof Smirnov menunjukan nilai CDI pada responden terpapar memiliki distribusi tidak normal $(p<0,05)$, sama halnya dengan responden kontrol distribusi dibawah 0,05.

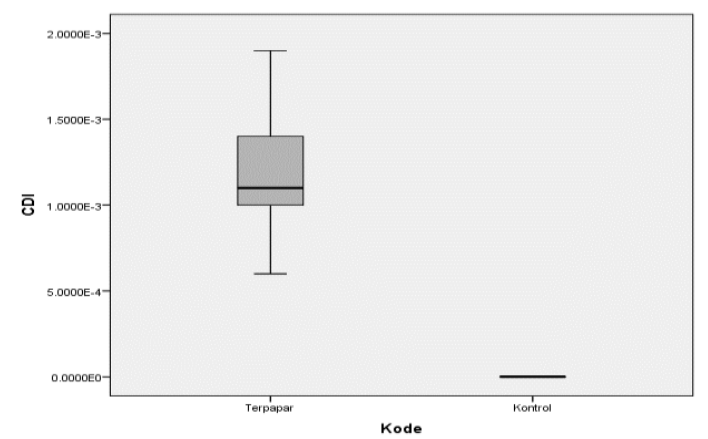

Gambar 5. Nilai CDI pada responden terpapar dan kontrol

Terpapar

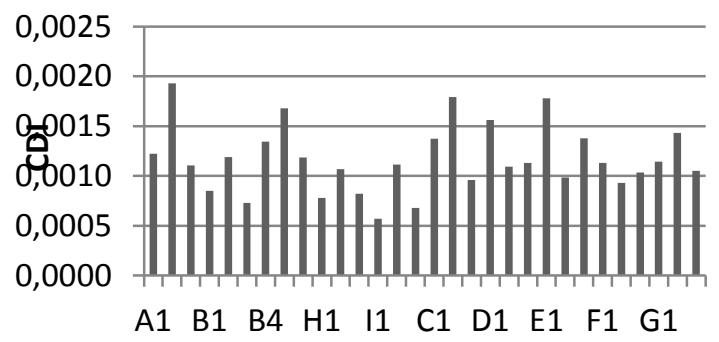

Responden

Gambar 6. Distribusi CDI pada responden terpapar

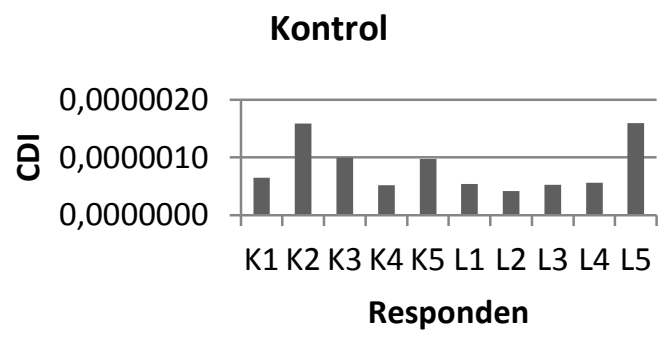

Gambar 7. Distribusi CDI pada responden kontrol

\section{Hazard Index (HI)}

Berdasarkan perhitungan Hazard Index (HI) pada kelompok responden terpapar didapat nilai HI berkisar antara 0,0017-0,0054 dengan rata-rata 0,0035 . Pada kelompok responden kontrol nilai HI berkisar 0,0000013-0,0000048 dengan rata-rata nilai sebesar 0,0000025.

Dari nilai sebaran HI pada Gambar 8. dapat dilihat bahwa hazard index dibawah 1, yang berarti tingkat bahaya paparan isopropanol yang rendah. Tetapi tingkat bahaya yang rendah bukan berarti bisa diabaikan, bila ada campuran bahan kimia lainnya dapat mempengaruhi kesehatan pekerja percetakan.

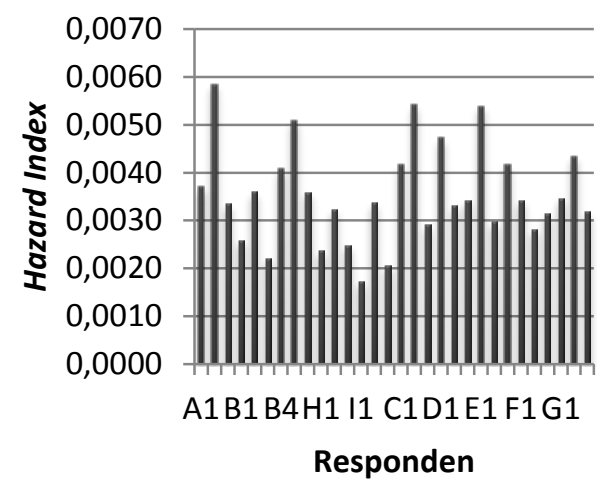

Gambar 8. Sebaran nilai Hazard Index (HI)

Regresi logistik multinomial

Hasil uji regresi logistik multinomial menganalisis variabel terikat urin dan variabel bebas hasil pengukuran isopropanol diudara. Hasil pengukuran paparan isopropanol, dilihat nilai $\operatorname{Exp(B)}$ nilainya 0,940 artinya setiap peningkatan satu unit hasil pengukuran paparan isopropanol kecenderungn mendapat nilai kristal oksalat dalam urin 1-5 sebanyak 0,940 kali lipat dari nilai tertinggi kristal oksalat dalam urin yaitu nilai $>30$. Artinya bahwa hasil paparan isopropanol mempunyai pengaruh yang besar terhadap konsentrasi kristal oksalat di urin.

Tabel 2. Tabel hasil regresi logistik multinomial

\begin{tabular}{|l|c|c|c|c|}
\hline Effect & \multicolumn{1}{|l|}{$\begin{array}{c}\text { Model } \\
\text { Fitting } \\
\text { Criteria }\end{array}$} & \multicolumn{2}{|l|}{ Likelihood Ratio Tests } \\
\cline { 2 - 5 } & $\begin{array}{c}-2 \text { Log } \\
\text { Likelihood } \\
\text { of } \\
\text { Reduced } \\
\text { Model }\end{array}$ & $\begin{array}{c}\text { Chi- } \\
\text { Square }\end{array}$ & df & Sig. \\
\hline Intercept & $61.111^{\text {a }}$ & .000 & 0 &. \\
\hline Usia & 67.100 & 5.989 & 3 & .112 \\
\hline $\begin{array}{l}\text { Hasil_udar } \\
\text { a }\end{array}$ & 80.694 & 19.583 & 3 & .000 \\
\hline $\begin{array}{l}\text { Penggunaa } \\
\text { n_masker }\end{array}$ & 65.300 & 4.189 & 3 & .242 \\
\hline
\end{tabular}

Hasil pengukuran konsentrasi isopropanol di udara pada penelitian ini lebih besar dibandingan pada penelitian Kristin Svendsen et al (2000) di Norwegia, dimana hasil pengukuran paparannya sebesar 0,8-100 ppm 
(TLV di Norwegia 100 ppm) pada pekerja percetakan.

Pada penelitian ini paparan isopropanol terhadap pekerja percetakan masih dibawah NAB yang ditetapkan akan tetapi bila paparan isopropanol terus memapari pekerja selama bekerja maka dapat menyebabkan risiko kesehatan pada pekerja percetakan tersebut. Terlebih lagi bila penggunaan konsentrasi isopropanol berlebihan pada proses pencetakan dan ditambah dengan paparan bahan kimia lain yang ada di percetakan offset.

\section{KESIMPULAN}

Konsentrasi isopropanol di udara sebesar 237,5317 ppm, konsentrasi isopropanol masih pada batas aman dibawah nilai NAB yang ditetapkan. Hasil analisis kristal oksalat pada urin dengan metode pengamatan secara mikroskopis, menunjukan sedimentasi kristal oksalat pada responden terpapar sebesar $43,33 \%$ pada nilai 5 10.

Korelasi paparan isopropanol di udara dengan sedimentasi kristal oksalat di urin menunjukan korelasi yang sangat kuat berkisar 0,5 hal tersebut menunjukan bahwa semakin tinggi paparan isopropanol maka sedimentasi krital oksalat semakin tinggi.

Hasil analisis dosis-respon yaitu nilai Chronic Daily Intake (CDI) dari pekerja cukup bervariasi, sedangkan untuk Hazard Index (HI) semua nilai $\mathrm{HI}$ responden lebih kecil dari 1.

Hasil analisis statistik menggunakan regresi logistik multinomial menunjukkan bahwa hasil pengukuran udara, penggunaan APD (masker) dan usia pekerja mempunyai nilai yang signifikan terhadap nilai kristal oksalat dalam urin pekerja.

\section{DAFTAR PUSTAKA}

Brugnone,F,at.all. (1983) : Isopropanol Exposure : Environmental And Biological Monitoring In A Printing Works. British Journal of Industrial Medicine, 40(2). 160-168.

Burleigh-Flayer $\mathrm{H}^{1}$, Garman $\mathrm{R}$, Neptun $\mathrm{D}$, Bevan $\underline{\mathrm{C}}$, Gardiner T, Kapp R, Tyler T, Wright G. (1997) : Isopropanol Vapor Inhalation Oncogenicity Study In Fischer 344 Rats And CD-1 Mice. Fundam Appl Toxicol, 35(2). 95-111.

Carko,Budiyanto. (2010) : Faktor Predisposisi Yang Berpengaruh Terhadap Kejadian Dermatitis Kontak Akibat Kerja Pada Percetakan. Fakultas Kedokteran, Universitas Sebelas Maret.

Environmental Protection Agency (EPA). (1986) : Guidelines for Carcinogen Risk Assessment. 51 Federal Register 33992 (September 24, 1986).

Gandosoebrata, R. (2010). Penuntun Laboratorium Klinik. Jakarta : Dian Rakyat.
Health and Savety Executive (HSE).Solvent Vapour Degreasing Plant (Use, Maintenance And Cleaning). www.hse.gov.uk/pubns/eis47.pdf. (diunduh tanggal 8 Mei 2015)

Hussain,Ali et.al.2014. Occupational Exposure to Cleaning Solvents Among Workers of Screen Printing Units in Pakistan: $A$ Preliminary Survey. Biological Sciences and Pharmaceutical Research, 2(5). 45-48.

Kiurski J.,Maric B., et.all.2012. The Impact Faktors of the Environmen Pollution and Workers Healt in Printing Industry. International Scholarly and Scientific Research \& Innovation, 6(1). 755-758.

Kristin, Svendsen.,Kari,

Rognes.2000. Exposure to Organic Solvent in the Offset Printing Industry in Norway. Oxford Journal, 44(2). 119-124.

National Institute of Health,US. National Library of Medicine. Toxicology Data Network.http://toxnet.nlm.nih.gov/cgibin/sis/ search/r?dbs+hsd:@term+rn+67-63.0. (diunduh tanggal 28 Mei 2015)

National Institute of Occupational Safety and Health. (NIOSH) 2549. www.emedco.info/nmam/pdfs/2549.pdf. (diunduh tanggal 10 november 2013)

NIOSH Hazard Review. (2000) : Carbonless Copy Paper. www.cdc.gov/niosh/docs/2001107.pdf. (diunduh tanggal 16 November 2013)

New Jersey Department of Health. (2011) : Hazardous Substance Fact Sheet: Isopropyl Alcohol.www. nj.gov/health/eoh/rtkweb/documents/fs/107 6.pdf. (diunduh tanggal 11 Mei 2015)

Soemirat, J. (2000) : Diktat Kuliah : Hiegene Industri. KBK Keselamatan dan Kesehatan Lingkungan. Program Studi Teknik Lingkungan. Institut Teknologi Bandung.

Rahmatullah, Masita, M.Furqon., Masyitha. (2013) : Keamanan Bahan Kimia Berbahaya pada Karyawan Percetakan Kota Makassar. Repository Universitas Hasanudin.

Tak-Sun Yu,Ignatius, Nga Lan Lee and Tze wai Wong. (2005) : Knowledge, Attitude and Practice Regarding Organic Solvents among Printing Workers in Hong Kong. J Occup Health, 47. 305-310

Williams, P.L., Bursom, J.L. (1985) : Industrial Toxicology: Safety and Health Applications in the Workplace. Van Nostrad Reinhold. New York

Winder, C., Stacey, N. (2005) : Occupational Toxicology. $2^{\text {nd }}$ edition.CRC Press.Boca Raton, London, New York, Washington D.C. 